\title{
Ewa Rowińska-Zakrzewska
}

Emerytowany Profesor Instytutu Gruźlicy i Chorób Płuc w Warszawie

\section{Rozpoznawanie śródmiąiszowych chorób płuc}

\author{
Recognition of interstitial lung diseases
}

Praca nie była finansowana

W pojęciu rozlanych śródmiąższowych chorób płuc mieszczą się jednostki chorobowe o nieznanej przyczynie oraz zmiany wtórne w stosunku do innych czynników. W pierwszej grupie znajdują się idiopatyczne śródmiąższowe zapalenia płuc i sarkoidoza oraz według klasyfikacji American Thoracic Society/European Respiratory Society (ATS/ERS) również rzadkie choroby, takie jak limfangiomyomatoza (LAM, lymphangiomyomatosis), płucna postać ziarniniakowatości typu Langerhansa (PLCH, pulmonary Langerhans' cell histiocytosis), eozynofilowe zapalenia płuc oraz proteinoza płuc (PAP, pulmonary alveolar proteinosis) $[1,2]$.

Idiopatyczne śródmiąższowe zapalenia płuc obejmują według najnowszej klasyfikacji 8 jednostek chorobowych, które charakteryzują się odmiennym przebiegiem klinicznym, obrazem radiologicznym płuc i obrazem histopatologicznym, a także rokowaniem i ewentualną metodą leczenia [3].

W grupie zmian powodowanych innymi czynnikami znajdują się pylice płuc [4], zmiany śródmiąższowe płuc w przebiegu chorób tkanki łącznej [5-7], choroby przewodu pokarmowego i wątroby [8, 9], alergiczne zapalenie pęcherzyków płucnych spowodowane uczuleniem na antygeny inhalacyjne [10] oraz zmiany polekowe [11]. Rozpoznawanie charakteru zmian rozsianych w płucach stanowi więc duży problem, gdyż nie tylko wchodzi tu $\mathrm{w}$ rachubę ogromna grupa samoistnych i wywołanych innymi czynnikami chorób śródmiąższowych, ale również zakażenia i nowotwory.

Rozpoznanie choroby śródmiąższowej według powszechnie przyjętych wytycznych wymaga konsultacji specjalisty chorób płuc, radiologia i patologa w tych przypadkach, w których wykonano biopsję płuca [1, 3, 12].

Rola klinicysty jest bardzo znaczna, gdyż poza przedmiotową oceną stanu chorego wymaga ustalenia czasu trwania choroby, jej objawów, ewentualnych chorób współistniejących, ich leczenia oraz potencjalnych szkodliwości środowiska, w tym również palenia papierosów czy używania narkotyków. Pozwala to na wykluczenie obecności zmian śródmiąższowych w płucach w wyniku działania wielu czynników zewnętrznych [13].

Do ogromnego postępu w ostatnich latach doszło w diagnostyce radiologicznej, w tym przede wszystkim w ocenie tomografii komputerowej o wysokiej rozdzielczości (HRCT, high-resolution computer tomography). Rolę HRCT w rozpoznaniu samoistnego włóknienia płuc (IPF, interstitial pulmonary fibrosis) opracował konsensus ERS, ATS oraz japońskich i południowoamerykańskich Towarzystw Chorób Klatki Piersiowej i Oddychania [12].

Wiadomo, że przy typowym obrazie HRCT i odpowiadających mu danych klinicznych i czynnościowych biopsja płuca nie jest konieczna.

W marcu 2013 roku przy okazji kolejnej nowelizacji klasyfikacji samoistnych śródmiąż-

Adres do korespondencji: prof. dr hab. n. med. Ewa Rowińska-Zakrzewska, Instytut Gruźlicy i Chorób Płuc w Warszawie, tel.: 224312177 ,

e-mail: monika.szturmowicz@gmail.com

DOI: 10.5603/PiAP.2014.0025

Praca wpłynęła do Redakcji: 21.02.2014 r.

Copyright (C) 2014 PTChP

ISSN 0867-7077 
szowych zapaleń płuc podano również zasady, na podstawie których można rozpoznać bez biopsji śródmiąższową chorobę płuc związaną z zapaleniem oskrzelików (RB-ILD, respiratory bronchiolitis associated interstitial lung disease) [3]. Ograniczeniem rozpoznania choroby śródmiąższowej na podstawie biopsji jest fakt, że wycinki pobrane z różnych płatów płuca mogą wykazywać odmienny obraz histopatologiczny (na przykład w jednym płacie stwierdza się UIP (usual interstitial pneumonia) — zwykłe śródmiąż̇zowe zapalenie płuc charakterystyczne dla IPF, a w drugim NSIP (non-specific interstitial pneumonia) - niespecyficzne śródmiąższowe zapalenie płuc. Ponadto UIP, jakkolwiek charakterystyczne dla IPF, może również odpowiadać włóknieniu płuc w przebiegu reumatoidalnego zapalenia stawów, bądź występować w przebiegu azbestozy. Obraz histologiczny NSIP nie musi świadczyć o samoistnej postaci tej choroby. $\mathrm{W}$ wielu przypadkach towarzyszy chorobie tkanki łącznej, bądź ją wyprzedza, może też występować $\mathrm{w}$ przebiegu odczynów polekowych lub towarzyszyć alergicznemu zapaleniu pęcherzyków płucnych $[5,6,13,14]$. Niespecyficzne śródmiąższowe zapalenie płuc bywa także rozpoznawane we wstępnym okresie zakażenia HIV [15].

Otwarta biopsja płuca, a nawet biopsja w czasie torakoskopii przedstawiają znaczne ryzyko dla osób znajdujących się w niewydolności oddechowej [13]. Rolę biopsji płuca ogranicza się więc do przypadków niejasnych i takich, w których ustalenie rozpoznania może doprowadzić do efektywnego leczenia. Na ogół w tych przypadkach poleca się biopsję otwartą lub przy zastosowaniu torakoskopii. Biopsja z udziałem bronchoskopii ma największe zastosowanie w rozpoznaniu sarkoidozy i procesów nowotworowych. W chorobach śródmiąższowych uzyskany materiał często nie jest reprezentatywny dla całego procesu chorobowego [15]. Wykonanie bronchoskopii $\mathrm{z}$ pobraniem materiału na badanie cytologiczne i bakteriologiczne często pozwala jednak na wykluczenie procesu nowotworowego i zakażeń (w tym gruźlicy) [16].

W ostatnim okresie podkreśla się również, że rolę pomocniczą może odgrywać analiza komórek uzyskanych za pomocą płukania oskrzelowo-pęcherzykowego (BAL, bronchioalveolar lavage) [17]. Może ona być decydująca przy rozpoznaniu krwawienia pęcherzykowego, kwasochłonnych zapaleń płuc czy proteinozy. Podwyższony odsetek limfocytów w BAL w bardzo dużym stopniu wyklucza rozpoznanie IPF [18]. Stosunek limfocytów CD4 do CD8 pozwala prowadzić dalsze badania w kierunku alergicznego zapalenia pęcherzyków płucnych lub sarkoidozy.

W aktualnym numerze „Pneumonologii i Alergologii Polskiej” autorzy z Indii [19] przedstawili swój materiał chorych ze zmianami śródmiąższowymi w płucach. Zwraca uwagę znaczny stopień zaawansowania zmian u przedstawionych chorych i długi czas, jaki upłynął od pierwszych objawów - wynosił on średnio 3 lata. Nic więc dziwnego, że bardzo wielu chorych w chwili przyjęcia do szpitala miało duszność. Autorzy podkreślają, że świadomość dotycząca chorób śródmiąższowych w Indiach nie jest rozpowszechniona, a ponadto znaczne rozpowszechnienie gruźlicy (zapadalność 107/100 000) w 2011 roku [20] powoduje, że zmiany rozsiane w płucach mogą być traktowane jako gruźlica i leczone przeciwprątkowo przed przyjęciem do szpitala. Taką sytuację obserwowali w części swoich przypadków.

Kumar i wsp. [19] ustalali rozpoznanie chorób śródmiąższowych na podstawie danych klinicznych i laboratoryjnych, badań czynnościowych układu oddechowego i HRCT. Wykonywali również biopsję poprzez bronchofiberoskop, która okazała się najczulszym badaniem w sarkoidozie. W materiale reprezentowane są różne typy chorób śródmiąższowych, największą liczbę stanowią jednak choroby samoistne. Zwraca uwagę niespotykana $w$ innych zestawieniach duża liczba przypadków NSIP. Być może część z nich nie miała charakteru samoistnego. Wiadomo bowiem, że u części pacjentów w czasie obserwacji rozwijają się objawy choroby tkanki łącznej $[5,6]$. Istnieje jednak możliwość, że wyższa częstość występowania NSIP w materiale autorów ma związek z predyspozycją genetyczną. Mogłyby to potwierdzić badania autorów amerykańskich, którzy udowodnili istnienie NSIP jako niezależnej, samoistnej jednostki chorobowej i stwierdzili, że większość tak określonych przez nich przypadków pochodziła z Azji [14].

\section{Konflikt interesów}

Autorka deklaruje brak konfliktu interesów.

\section{Piśmiennictwo:}

1. American Thoracic Society/European Respiratory Society International Multidisciplinary Consensus Classification of the idiopathic Interstitial pneumonia. Am. J. Respir. Crit. Care Med. 2002; 165: 277-304.

2. Rowińska-Zakrzewska E., Bestry I. Choroby śródmiąższowe płuc. W: Szczeklik A. (red.). Interna Szczeklika, Medycyna Praktyczna, Kraków 2013: 696-706.

3. Travis W.D., Costabel U., Hansel D.M. i wsp. An official American Thoracic Society: European Respiratory Society statement: 
Update of the international multidisciplinary classification of the idiopathic interstitial pneumonias. Am. J. Respir. Crit. Care Med. 2013; 188: 733-748.

4. Marek K., Pałczyński C., Górski P. Choroby zawodowe układu oddechowego. W: Szczeklik A. (red.). Interna Szczeklika, Medycyna Praktyczna, Kraków 2013: 745-753

5. Fischer A., West S.G., Swigris J.J., Brown K.K., du Bois R.M. Connective tissue disease-associated interstitial lung disease. Chest 2010; 138: 251-256.

6. Vij R., Strek M.E. Diagnosis and treatment of connective tissue disease-associated interstitial lung disease. Chest 2013: 143: 814-824.

7. Bartosiewicz M., Siemion-Szcześniak I., Sobiecka M. i wsp. Zmiany śródmiąższowe $\mathrm{w}$ płucach $\mathrm{u}$ chorych na zapalenie wielomięśniowe i skórno-mięśniowe - prezentacja 3 przypadków. Pneumonol. Alergol. Pol. 2013; 81: 556-566.

8. Bartosiewicz M., Siemion-Szcześniak I., Jędrych M. i wsp. Zmiany śródmiąższowe w płucach chorych na pierwotną żółciową marskość wątroby. Pneumonol. Alergol. Pol. 2012; 80: 467-481.

9. Martusewicz-Boros M., Rowińska-Zakrzewska E. Zmiany śródmiąższowe $\mathrm{w}$ płucach $\mathrm{w}$ przebiegu chorób przewodu pokarmowego. W: Wiatr E., Rowińska-Zakrzewska E., Pirożyński M. (red.). Choroby śródmiąższowe płuc. alfa-medica press 2012: 254-263.

10. Radzikowska E. Alergiczne zapalenie pęcherzyków płucnych. W: Wiatr E., Rowińska-Zakrzewska E., Pirożyński M. (red.). Choroby śródmiąższowe płuc. alfa-medica press 2012: 124-133.

11. Wiatr E. Polekowa i popromienna choroba śródmiąższowa płuc. W: Wiatr E., Rowińska-Zakrzewska E., Pirożyński M. (red.). Choroby śródmiąższowe płuc. alfa-medica Press 2012: 134-149.
12. Raghu G., Collard H.R., Egan J.J. i wsp. An official ATS/ERS/ JRS/ALAT Statement: idiopathic pulmonary fibrosis: Evidence-based guidelines for diagnosis and management. Am. J. Respir. Crit. Care Med. 2011; 183: 788-824.

13. Rowińska-Zakrzewska E. Rozpoznawanie chorób śródmiąższowych płuc. W: Wiatr E., Rowińska-Zakrzewska E., Pirożyński M. (red.). Choroby śródmiąższowe płuc. alfa-medica press 2012: 21-25.

14. Travis W.D., Hunninghake G., King T.E. Jr. i wsp. Idiopathic nonspecific interstitial pneumonia. Am. J. Respir. Crit. Care Med. 2008; 177: 1338-1347.

15. Doffman S.R., Miller R.T. Interstitial lung disease in HIV. Clin. Chest Med. HIV and Respir. Dis. 2013; 34: 293-306.

16. Pirożyński M., Pirożyńska E., Wiatr E. Bronchoskopia, przezoskrzelowa biopsja płuca i płukanie oskrzelowo-pęcherzykowe. W: Wiatr E., Rowińska-Zakrzewska E., Pirożyński M. (red.). Choroby śródmiąższowe płuc. alfa-medica press 2012: 91-102.

17. Meyer K.C., Raghu G., Baughman R.P. i wsp. An official American Thoracic Society Clinical Practice Guideline: The clinical utility of bronchoalveolar lavage cellular analysis in interstitial lung disease. Am. J. Respir. Crit. Care Med. 2012; 185: 1004-1014.

18. Ohshimo S., Bonella F., Cui A., i wsp. Significance of bronchoalveolar lavage for the diagnosis of idiopathic pulmonary fibrosis. Am. J. Respir. Crit. Care Med. 2009; 179: 1043-1047.

19. Kumar R., Gupta N., Goel N. Spectrum of interstitial lung disease at a tertiary care centre in India. Pneumonol. Alergol. Pol. 2014; 82: 218-226

20. Global Tuberculosis Report, 2012, WHO. 